\title{
Bespoke career up-skilling: the case of Mellon Skills Accelerator
}

\author{
Konstantin Tsimas (D)
}

Correspondence: k.tsimas@knowl.gr 335 Acharnon Street, 11145 Athens, Greece

\begin{abstract}
In the absence of a sufficient number of state-run institutional interventions, any action stemming from autonomous, voluntary private sector initiatives providing counseling and up-skilling to unemployed women is de facto important, especially when referring to confirmed successful and recurring efforts. This contribution provides a detailed discussion and analysis of the methodological approach and extraordinary results of the "Mellon Skills Accelerator" initiative, designed and delivered by knowl Social Enterprise to increase employability. It provides a preliminary evaluation of the initiative's impact and suitability to be adopted as a standard course of action, across the Greek nation and possibly across Europe and beyond. The author has had firsthand experience of Mellon Skills Accelerator working as a volunteer counsel and coach with the organization.
\end{abstract}

Keywords: Greek crisis, women's unemployment, Up-skilling, Counseling, Training, Reemployment

\section{Introduction}

Over the past decade, the prolonged multi-faceted crisis in Greece has profoundly affected the economic, political and, most importantly, social structures and behavior of the Greeks and most of the country's population groups. Among the commonly quoted symptoms of a grim reality now spanning almost 10 years are dramatic loss of income due to widespread salary cuts and persistent chronic unemployment, diminished entrepreneurship opportunities due to the collapse of bank controlled capital availability, and dire insecurity about the future among pensioners, workers, and entrepreneurs alike further shrinking the market and employment opportunities in the private sector. Such symptoms have produced reactions including extensive tax avoidance, collective rejection of traditional open-consultation and problem-solving procedures, and widespread pessimism and depression, as well as strengthening of extremist political voices and choices.

Among the distinct groups where significant losses in employment and entrepreneurship opportunities are consistently recorded, women and older workers compete for pole position. In cold statistical data, the difference in unemployment rates between women and men is increasing (to the detriment of women), irrespective of the general trend of the index. During the latter half of the crisis, when total unemployment rates were marginally dropping, the percentile difference between men and women was

(c) The Author(s). 2020 Open Access This article is distributed under the terms of the Creative Commons Attribution 4.0 International License (http://creativecommons.org/licenses/by/4.0/), which permits unrestricted use, distribution, and reproduction in any medium, provided you give appropriate credit to the original author(s) and the source, provide a link to the Creative Commons license, and indicate if changes were made. 
actually growing, from 6.4 to 8.0 points (ELSTAT, 2018). Men's unemployment was dropping almost twice as fast. Women continue to be far more disadvantaged in terms of entering and remaining in the labor market. This is due to standing inequalities, persisting stereotypes, and archaic social perceptions of gender roles, despite the significant institutional and legislative measures introduced at the national and European level, aiming to reconcile work and family life, during the past 10-year period (Karamasin, Skoba \& Chatzivarnava, 2016).

Unemployment is definitely a sad state of affairs for both men and women, not only at a purely material level (loss of income and consequent poverty, especially in the case of prolonged unemployment), but also psychologically (survival anxiety, depression, anti-social behavior, eventual marginalization). At the same time, the overall structure and internal relations of the labor market are changing rapidly, making it difficult to monitor the progress and effectiveness of any strategic responses adopted-especially for the long-term unemployed. Both the introduction of the concept of "employability" and the conversion processes of chance events into employment opportunities require increased alertness and specialized training so that the unemployed are able to self-manage both their careers and their lifelong development (Sidiropoulou-Dimakakou, Bezevegi, Argyropoulou \& Drosos, 2013).

Disadvantages are similarly recorded for women engaged in entrepreneurship in Greece. Their involvement is approx. 15 points lower than the European average (20\% vs. $34.4 \%$ ), due to established misperceptions and patriarchal attitudes that continue to discredit female entrepreneurship despite the positive institutional interventions (Stavropoulou, Salamouris \& Ligas, 2015).

Almost 15 years ago, the European Commission and the Organization for Economic Cooperation and Development (OECD) stressed the importance of vocational guidance and career counseling, prioritizing these practices as key axes for achieving the four objectives of the Common European Policy for Development (OECD-EC, 2012). The four objectives were lifelong learning, social integration, effectiveness in finding work, and economic development at the community level.

The Greek state, given its general economic failing and the continuous procedural dysfunctions caused not only by the implementation of the bailout Memoranda obligations but also by other restrictions indirectly brought about by frequent changes of political priorities, appears to rely on the Human Resources Development, Education and Lifelong Learning Program, 2014-2020, put forth by the Ministry of Labor. ${ }^{1}$ There are no other large-scale projects and the said Program's planned actions posted on the internet ended in 2015. Since then, only smaller, targeted projects are reported. Larger-scale systemic interventions are absent (Ministry of Labor, 2018). One would logically expect the so-called "market forces" to efficiently substitute the state and satisfy, to the extent possible, typically basic requirements. Such is the case with the non-systemic intervention "Mellon Skills Accelerator" implemented by knowl Social Enterprise.

\footnotetext{
${ }^{1}$ Ministry of Labor, National Technical University of Athens 2014-2020. http://www.epanad.gov.gr/default. asp?pID $=17 \& l a=1$
} 


\section{Methods}

Material for this commentary has been collected through private interviews carried out by the author during his volunteer service with knowl Social Enterprise. Actual numerical data was provided via publicly available sources, as noted.

\section{Discussion-the case of knowl's Mellon project}

Amalia K., an industrious woman in her early fifties, had never been short of ideas to keep herself productively busy. Managing to keep in touch with the real world since a young age irrespective of setbacks and difficulties, she tried to fight off the current mega-crisis utilizing her usual mix of good humor and hyper activity. Amalia had a long presence in the cosmetics and beauty market, offering personal advice on ladies' make-up choices and techniques. Her business title was "coloring expert". But, despite increased efforts, the market simply wasn't there anymore. She opted for serious change and was admitted to Mellon Skills Accelerator's 5th Round for the unemployed of the Municipality of Kallithea, Athens. She claims her experience in Mellon was lifechanging and her contribution to the seminars and counseling sessions was unanimously honored by her mentors and colleagues during her graduation in December, 2017. Amalia, currently enrolled for a Home Economics and Ecology Studies degree at the Athens Harokopeion University, already plans her next business move. She manages to find the time to participate in knowl's other activities geared towards the older long-term unemployed, providing useful insights for other participants and encouraging them to up-skill. Amalia considers herself a dedicated "Mellonee" and is constantly promoting the scheme.

knowl Social Enterprise has been operating since its establishment in 2012 as a dynamic collaborative network of scientists (economists, sociologists, psychologists, volunteer counsels, and adult educators), based on the principles of social economy and entrepreneurship. ${ }^{2}$ knowl focuses on the free provision of personal counseling, education, and training services to vulnerable social groups, aiming at combating unemployment, poverty, and marginalization. The majority of the beneficiaries through knowl's various actions and initiatives consists of women as well as older (45+) long-term unemployed who do not have access to further training and possess limited skills. In the first 5 years of its activity, knowl has fulfilled short-term training programs for over 4000 people and coorganized interactive training seminars for more than 6000 people.

In 2015, knowl presented the innovative social initiative "Mellon Skills Accelerator", based entirely on an idea by the organization's Chief Visionary Officer, Olga Stavropoulou. The aim of the initiative was, quite simply, to speedily increase the employability of unemployed beneficiaries through their personal empowerment and the acquisition of appropriate soft and professional skills. The procedure followed puts the emphasis on short duration (a few months) and is always provided without any financial burden on the beneficiaries.

There are three distinct steps in each "Mellon" occurrence. First, a detailed diagnosis of personal strengths and needs of each beneficiary, aided by a psychometric questionnaire and completed by volunteer counsels and coaches on a one-to-one basis. Second, steps towards empowering the beneficiaries along their personal "road map" draft, a

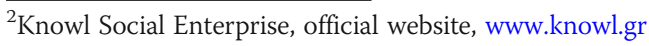


personalized "masterplan" which includes private and group practical training sessions and soft-skills seminars. Third, the final formal preparation for re-entering the labor market, via customized curriculum vitae drafting and re-employment tactics consulting. At the end, all participants having successfully completed the full program "graduate" in a ceremony aimed at sealing their actual mindset transformation. All graduates have consistently voiced the positive effects of the full "Mellon" process. They receive a Certificate of Participation and are sent off, ready to compete in the demanding job search arena in a clearly advantageous position in relation to their condition before joining "Mellon". In fact, many of them (close to 15\%) manage to secure employment in a position of their choice prior to the Cycle's completion. The overall success rate for re-employment now tops 50\%, an outstanding feat.

Mellon Skills Accelerator actions are implemented with the support of Local Authorities, currently only in the Prefecture of Attica. Seven rounds have already been completed, while an 8th Cycle with the support of the Mitilineos Group (a major player in the Greek energy and metallurgy industry) served as a pilot in focused specialization efforts, targeting unemployed engineers. Cooperation with municipal authorities is required for the selection of the unemployed beneficiaries (aided by their Social Services and Lifelong Education departments), while it also ensures that adequate municipal facilities (private sessions and group training space) for group and individual meetings are made available.

Along with the implementation of the personalized agendas, each cycle is "enriched" by a number of educational workshops related to job finding, which are open to the public following pre-registration. Such open seminar events provide full, in-depth knowledge of a relevant topic and are always offered free of charge by established academics or seasoned market professionals. All participants receive a tracking certificate.

knowl's Mellon Skills Accelerator initiative has proven to be their most successful undertaking. The numbers are particularly revealing and they tell a truly impressive story ${ }^{3}$ :

- 3,500 people have been trained on a "priority" employment-related topic.

- 16,500 teaching hours have been completed.

- 33 professional skills seminars have been implemented.

- 8 Intensive Cycles completed in the municipalities of Acharnes, Aspropyrgos, Markopoulo, Galatsi, Kallithea, Vrilissia and Papagos-Holargos, plus the Mitilineos Group one.

- $50 \%$ of successful participants in the 8 Cycles have found employment corresponding to their professional goals.

An often omitted parameter in cases where numbers prosper but the people involved are not as satisfied, is the publication of feedback questionnaires. In the case of knowl, there is true satisfaction among beneficiaries: close to 660 positive testimonies, the majority of which are eponymous, are listed on knowl's website as an assertive message of an effective and fruitful empowerment and learning process. Public evaluations refer to group activities and open seminars training.

${ }^{3}$ Knowl Social Enterprise, www.mellon-accelerator.eu 
Mellon Skills Accelerator received top laurels in the 2016 Education Business Awards. knowl's initiative was also selected as "Good Practice" on the European I-LINC Platform to boost youth employment and entrepreneurship, as well as on a variety of networks and projects which promote the employability of people over 45 , social entrepreneurship, and the integration of migrants, under the aegis of the European Commission.

\section{Results-the powers behind Mellon's success}

Essentially, Mellon Skills Accelerator is an empowering tool, focusing on soft and practical skills, but also a mindset transformation scheme, aiming at elevating the beneficiaries' self-understanding, self-respect, and confidence. In most cases, the unemployed and long-term unemployed who are inducted have lost their career focus due to the rapidly changing, hostile labor market conditions, and as is the case in Greece, ill preparation and erratic decision-making in earlier career choices. Counsels, coaches, and mentors invest in turning such situations around. Available data confirm their effort to be largely successful.

Eleni T., a single mother in her late $30 \mathrm{~s}$, is a great example of such mindset transformation as mentioned above. A law school graduate, Eleni joined Mellon's 6th cycle hoping she would be able to overcome the Crisis' effects on her career and personal situation. She was compelled to surrender her license to practice law due to financial burden and believed she could only hope for a position as office assistant to sustain her child. Following knowl's counseling efforts, Eleni emerged from the program a sharply different woman. She quickly managed to get a proper position in a Law firm as a paralegal and now plans to reactivate her bar license, her income permitting. Those present at her Mellon graduation ceremony were moved by her short speech, relaying her transformation experience.

How exactly is the staffing of all counseling and educational services provided within "Mellon Skills Accelerator", one may well ask. This "infrastructural" design actually enables the project's spectacular results. A triangular scheme of opportunities is offered by individual volunteers, organizations, and enterprises, coordinated by a small administration group at knowl's headquarters. The most important vertex of this triangle includes a pool of 60-plus counsels, coaches, and trainers, aptly called Mellon Experts. They are distinguished professionals who are selected on the basis of the ability to coach people effectively, pass on knowledge, and provide a high level of learning experience. They constitute the central mechanism for the success of Mellon Skills Accelerator, and they provide their services gratis, with social generosity. The range of their specialties guarantees coverage of almost all the needs of the unemployed beneficiaries. ${ }^{4}$

On another vertex, Mellon angels comprise a group of over 30 ambassadors of the initiative. All of them are well-known, distinguished personalities in their fields, who carry special weight and impact on society. Several of the experts who are implementing the open seminars are drawn from this group. Others often provide expert mentoring of the highest level to beneficiaries. $^{5}$

Finally, at the third vertex of the triangle one can find Mellon's supporters. They include private institutions, corporations, organizations, and local authorities. All

\footnotetext{
${ }^{4}$ http://www.mellon-accelerator.eu/el/mellon-koinotita/mellon-experts

${ }^{5}$ http://www.mellon-accelerator.eu/el/mellon-koinotita/mellon-angels
} 
contribute in various ways to ensure the timely and complete execution of individual subprojects (cycles and workshops), but also offer their dissemination and communication efforts to the wider public. Important financial contributions have been secured from the Stavros Niarchos Foundation and the Bodossakis Foundation. One should not fail to mention the support provided by the Hellenic Society of Positive Psychology, OTE (Hellenic Telecoms Organisation) Academy and Microsoft Corporation.

Following Mellon's success, knowl has been selected by Prince's Trust International, HRH The Prince of Wales' global initiative to support young people, battle youth unemployment and aid youth entrepreneurship, as their prime implementation partner in Greece. Knowl's rich experience and know-how acquired over the successive Mellon cycles is currently being put to good use within PTI's programmes, implemented with active support from major Greek employers across various sectors (aviation, commerce, energy). It is particularly worth noting that over $70 \%$ of participants are women. One should add that knowl's interventions towards enlarging the opportunities offered to women-both in terms of their employability in the current crisis-laden labor market but also with the possibility to implement business plans (women's Entrepreneurship actions) - extend beyond the successive Mellon Skills Accelerator cycles. As over 70\% of Mellon participants are women, the opportunity is provided to those who attend, transform, improve, and succeed to communicate their unique experiences to other women while stimulating a will and vision for more widespread change. This informal action is named the "Double U Network", a network exclusively by women for women. ${ }^{6}$

\section{Conclusions}

What "Mellon Skills Accelerator" has proven so far is that a great idea can and will turn into a great, effective practice, provided there is support, commitment, and positive participation from the professional community. The summary overview of and commentary on knowl's Mellon Skills Accelerator presented here, largely stems from the author's personal engagement as an active volunteer counsel and trainer, an actual Mellon Expert. This has proven a highly enlightening experience as all counseling sessions with the unemployed were definitely unique. What personal experience has also proven, it takes the vision and seemingly inexhaustible positive energy stream of one person, Olga Stavropoulou, to seal a venture's success. She clearly knows how to provide the required encouragement and empowerment, both to the administration team and the participating unemployed beneficiaries, on a sustained basis. The fact that this whole project is offered free as a complete set, "know-how" and implementation methodology, to any interested party to replicate and enrich, is also noted as an exceptional practice.

Given the outstanding success rates of the successive "Mellon Skills Accelerator" cycles (over 50\% recorded employability), a retrospective long-term efficacy study remains to be completed, in order to ascertain that knowl's successful empowerment and mindset transformation efforts affect beneficiaries positively during their lifetime.

Abbreviations

ELSTAT: Elliniki Statistiki Arhi, Hellenic Statistics Authority; OECD: Organization for Economic Cooperation and Development; OTE: Organismos Telepikinonion Ellados, Hellenic Telecoms Organization

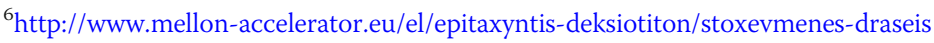




\section{Acknowledgements}

I would like to thank Ms. Olga Stavropoulou, knowl Social Enterprise's Chief Visionary Officer, for explaining Mellon Skills Accelerator, her brain-child, in the deepest detail during a series of private conversations. Many beneficiaries of various implementations of Mellon Skills Accelerator (6th, 7th and 8th in particular), contributed opinions and voiced words of praise which helped formulate parts of this presentation. These exchanges occurred during my volunteer counseling and coaching duties for knowl Social Enterprise.

\section{Authors' contributions}

KT was the sole contributor of the manuscript. The author read and approved the final manuscript.

\section{Authors' information}

Konstantin Tsimas is a sociologist-anthropologist (Swarthmore, 1982; Panteion, 1999) with extensive professional experience in marketing communications and management consulting. During the past five years he has received formal training as a career and education counsel (ASPETE; British Council) and coach and today provides services mainly to students and mature unemployed professionals as a freelance. He serves as a volunteer associated with knowl Social Enterprise where he also coordinates all the volunteers involved in the "Mellon Skills Accelerator" projects.

\section{Funding}

No funding whatsoever has been provided for this manuscript.

\section{Competing interests}

The author declares that he has no competing interests.

Received: 5 March 2019 Accepted: 8 January 2020

Published online: 12 February 2020

\section{References}

ELSTAT (Hellenic Statistical Authority). (n.d.). http://www.statistics.gr/el/statistics/-/publication/SJO02/2017-M01 Accessed 22 Oct 2018.

Karamasin, M., Skoba, M., \& Chatzivarnava, E. (2016). Bibliographic analysis and analysis of policies concerning the reconciliation of professional and family / private life. Athens: Laboratory of Gender Studies, Panteion University.

Ministry of Labor, National Technical University of Athens 2014-2020. (n.d.). http://www.epanad.gov.gr/default.asp?plD= $17 \& l a=1$ Accessed 30 Nov 2018.

OECD-EC (2012). Career Guidance: A Handbook for Policy Makers, 2004, as set out in General Secretariat for Lifelong Learning Sidiropoulou-Dimakakou, D., Bezevegis, H., Argyropoulou, A., \& Drosos, N. (2013). Developing lifelong career management skills: Implementation handbook for vocational guidance counselors. Athens: EOPIPEP.

Stavropoulou, O., Salamouris, I., \& Ligas, K. (2015). Entrepreneurship: for some it is trend, for some it is life choice. In Proceedings of the Scientific Conference "Entrepreneurship as Professional Selection \& Career Counseling", Consultation and Guidance Survey of ELESYP, Special Issue 105 (pp. 122-130).

\section{Publisher's Note}

Springer Nature remains neutral with regard to jurisdictional claims in published maps and institutional affiliations.

\section{Submit your manuscript to a SpringerOpen ${ }^{\circ}$ journal and benefit from:}

- Convenient online submission

- Rigorous peer review

- Open access: articles freely available online

- High visibility within the field

- Retaining the copyright to your article

Submit your next manuscript at $\boldsymbol{s p r i n g e r o p e n . c o m ~}$ 